\title{
SIKAP SOPAN SANTUN ANAK DILIHAT DARI POLA ASUH ORANG TUA TUNGGAL
}

\author{
Reza Nur Faizah ${ }^{1}$, Nur Fajrie ${ }^{2}$, Ratri Rahayu ${ }^{3}$ \\ Universitas Muria Kudus \\ Email:201733127@std.umk.ac.id
}

\begin{tabular}{ll}
\hline Info Artikel & Abstract \\
\cline { 1 - 2 } Sejarah Artikel: & $\begin{array}{l}\text { Parenting is a treatment or way of educating parents in order to meet the needs and } \\
\text { educate children in everyday life. In a family, the presence of parents is very } \\
\text { important for the development of a child's personality, because the family is the first } \\
\text { Diserahkan: } \\
\text { and foremost environment that will influence several aspects of child development, } \\
\text { including the child's polite attitude. But not all children have complete parents, there } \\
\text { are some children who are so unlucky that they only have one parent. But how to } \\
\text { educate single parents is not much different from parents who are intact in instilling } \\
\text { child courtesy. The cultivation of polite attitudes given by single parents to children } \\
\text { is to provide understanding of what is good and bad and to give good examples to } \\
\text { their children, so that children are more accustomed to seeing good things and can } \\
\text { be imitated by children in everyday life. In this article, we will describe the polite } \\
\text { behavior of children seen from the parenting styles applied by single parents. }\end{array}$ \\
Child's behavior, social
\end{tabular}

\begin{abstract}
Abstrak
Pola asuh adalah perlakuan atau cara mendidik orangtua dalam rangka memenuhi kebutuhan dan mendidik anak dalam kehidupan sehari-hari. Dalam sebuah keluarga, kehadiran orangtua sangatlah besar artinya bagi perkembangan kepribadian seorang anak, karena keluarga merupakan lingkungan pertama dan paling utama yang nantinya akan memberikan pengaruh terhadap beberapa aspek perkembangan anak, termasuk sikap sopan santun anak. Tetapi tidak semua anak memiliki orang tua yang utuh, ada beberapa anak yang kurang beruntung sehingga hanya memiliki satu orang tua saja. Tetapi cara mendidik orang tua tunggal tidak jauh berbeda dengan orang tua yang utuh dalam menanamkan sikap sopan santun anak. Penanaman sikap sopan santun yang diberikan dari orang tua tunggal kepada anak adalah memberikan pengertian akan mana yang baik dan yang buruk dan memberikan contoh yang baik kepada anaknya, sehingga anak lebih terbiasa melihat hal-hal yang baik dan dapat ditirukan anak dalam kehidupan sehari-hari. Pada artikel ini akan mendeskripsikan pendidikan sopan santun yang diterapkan orang tua tunggal kepada anaknya.
\end{abstract}




\section{Reza Nur Faizah, Nur Fajrie, Ratri Rahayu \\ SIKAP SOPAN SANTUN ANAK DILIHAT DARI POLA ASUH ORANG TUA TUNGGAL \\ JURNAL PRASASTI ILMU. Volume 1 Nomor 1 hlm. 13-18}

\section{PENDAHULUAN}

Keluarga merupakan satuan unit terkecil dari masyarakat yang terdiri dari laki-laki dan perempuan yang disatukan melalui ikatan perkawinan. Sebagai satuan terkecil, keluarga merupakan embrio dan miniatur berbagai unsur sistem sosial manusia. Suasana keluarga yang kondusif akan menghasilkan warga masyarakat yang baik karena dalam keluargalah seluruh anggota keluarga belajar berbagai dasar kehidupan masyarakat (Yasa \& Fatmawati, 2018).

Tetapi terdapat beberapa faktor-faktor yaitu perceraian, salah satu pasangannya meninggal, diterlantarkan psangannya yang menyebabkan sebuah keluarga menjadi tidak utuh dan menyebabkab seseorang menjadi orang tua tunggal.

Di desa Karangsari kabupaten Grobogan menunjukan bahwa terdapat beberapa orang tua tunggal atau single parents yang memiliki peran ganda dalam kehidupannya, singel perents memerankan peran ganda dalam mendidik anaknya dan bekerja untuk memenuhi kebutuhan hidupnya secara bersamaan. Orang tua tunggal tetap mendidik serta mengarahkan anaknya untuk membentuk sikap sosial yang baik dan anak mampu menyesuaikan diri dengan baik terhadap lingkungan masyarakat sekitar. Salah satunya pemberian pembiasaan-pembiasaan terhadap anaknya sehingga anak dari orang tua tunggal tetap memiliki sikap sopan santun yang baik, terutama dalam berinteraksi dengan lingkungan sekitar. Menurut Wiranti (2019) Orang tua memiliki peran yang sangat penting. Di usia anak dini ini, anak-anak masih bergantung dengan orang tua dalam mengembangkan segala potensinya.

Sopan santun merupakan sikap yang patuh, hormat, dan beradab. Menurut Zuriah (dalam Samsiyah 2020) menyampaikan sopan santun sebagai norma tidak tertulis yang mengatur bagaimana seharusnyabersikap dan berperilaku. Sebagai istilah dalam bahasa jawa, sopan santun dapat diartikan sebagai perilaku seseorang yang menjunjung tinggi nilai-nilai. Dengan kata lain, sopan santun adalah suatu tata cara atau aturan yang urun temurun dan berkembang dalam suatu budaya masyarakat. Yang bermanfaat dalam pergaulan dengan orang lain, agar terjalin hubungan yang akrab, saling menghormati, hormat menghormati menurut adat yang telah ditentukan. Menurut Puspa (2016) sopan santun ialah suatu tingkah laku yang amat populer dan natural. Sopan santun yang dimaksud adalah suatu sikap atau tingkah laku individu yang menghormati serta ramah terhadap orang yang sedang berinteraksi dengannya. Perwujudan dari sikap sopan santun ini adalah perilaku yang menghormati orang lain melalui komunikasi yang menggunakan bahsa yang tidak meremehkan atau merendahkan orang lain. Sopan santun secara umum adalah peraturan hidup yang timbul dari hasil pergaulan dalam kelompok sosial.

Sikap sopan santun yang dimiliki oleh anak sesuai dengan penanaman budi pekerti yang telah diberikan kepada anak sejak lahir oleh orang tua. Orang tua harus mencurahkan segenap perhatian dan kasih sayangnya terhadap anak. Sehingga nilai-nilai budi pekerti dapat diserap dengan baik oleh anak. Sehingga anak memiliki sikap sopan santun yang baik. Begitu juga keluarga sebagai lingkungan pertama dari seorang anak memiliki pengaruh yang besar terhadap tingkah laku anak dalam lingkungan sosial nantinya. Ketika anak memiliki sikap sopan santun yang baik dalam berinteraksi dengan lingkungannya maka anak memiliki sikap kepercayaan diri yang baik. Seperti yang diungkapkan oleh Rahayu (2014) bahwa kepercayaan anak memberi kekuatan yang dapat mempengaruhi pada penilaian kemampuan anak dan kesediaan untuk mengerjakan tugas.

Seiring dengan perkembangan zaman dan cara berfikir seseorang terdapat hakikat sebuah perkawinan. Perkawinan adalah hal yang sakral. Namun, perkawinan sering mengalami persoalan yang mengancam keharmonisannya. Hal ini bisa disebabkan oleh faktor ekonomi, dan permasalahn lainnya yang tidak dapat diselesaikan dan dapat menyebabkan keretakan yang menimbulkan perceraian bahkan diterlantarkan pasangannya. Tidak hanya perceraian dan diterlantarkan pasangannya yang menjadikan sebiah orang tua menjadi seorang single parent atau orang tua tunggal, faktor kematian pada salah satu pasangan suami istri juga menimbulkan peran sosial baru yaitu single parent atau orang tua tunggal. Menurut Samsiyah (2020) menyatakan bahwa orang tua tunggal adalah seseorang yang mengurus rumah maupun anak-anak serta dirinya sendiri tanpa kehadiran, dukungan, dan tanggung jawab dari pasangannya. Menjadi orang tua tunggal bukanlah perkara yang mudah, karena peran mendidik, menafkahi, dan menjaga anak yang sejatinya dilakukan berdua antara suami dan istri, mau tidak mau menjadi tanggungan diri sendiri.

Status orang tua tunggal membawa 


\section{Reza Nur Faizah, Nur Fajrie, Ratri Rahayu \\ SIKAP SOPAN SANTUN ANAK DILIHAT DARI POLA ASUH ORANG TUA TUNGGAL \\ JURNAL PRASASTI ILMU. Volume 1 Nomor 1 hlm. 13-18}

konsekuensi tersendiri pada perubahan peran pada orang tua tunggal tersebut. Orang tua tunggal tidak hany amenjadi seorang ibu saja tetapi harus juga menjadi ayah, begitupula sebaliknya yang memiliki peran mengurus rumah tangga namun juga harus mencari nafkah dan harus bertanggung jawab penuh baik dalam bidang ekonomi, pendidikan dan cara pengambilan keputusan yang tepat untuk kelangsungan hidup.

Banyak kemungkinan hal yang terjadi pada anak yang dikarenakan kurangnya intensitas pengasuhan yang dilakukan orang tua tunggal. Didalam perhatian yang seharusnya didapatkan oleh anak untuk membentuk perilaku sopan santun dari orang tuanya tidak terpenuhi dengan baik. Tetapi ada juga anak yang mendapatkan perhatian yang baik oleh orang tua tunggalnya dalam menanamkan nilainilai sopan santun. Dengan segala keterbatasan dan peran ganda yang dipegang oleh orang tua tunggal maka tugas dalam mengawasi dan mendidik anak juga terdapat hambatan sehingga peran orang tua tunggal dalam hal mendidik anak tidak dapat dijalankan secara maksimal. Tetapi adapula orang tua tunggal yang dapat membagi waktu yang baik antara mengurus rumah, mencari nafkah dan mendidik anak dalam penanaman sikap sopan santun.

Orang tua tunggal yang menggunakan pola pengasuhan demokratis maka akan terbentuk sikap anak yang sopan, tetapi ada juga anak yang diasuh dengan pola pengasuhan demokratis tetapi anak memiliki sikap yang kurang santun, hal tersebut terjadi karena faktor lingkungan yang kurang mendukung untuk penanaman nilai-nilai sopan santun pada anak. Ada pula anak yang diasuh dengan pola pengasuhan permisif yaitu membiarkan tetapi sikap anak mampu memiliki sikap sopan santun yang baik. Hal tersebut dikarenakan faktor lingkungan anak yang mendukung untuk penanaman sikap sopan santun pada anak. Menurut Hulukati (2015) Lingkungan keluarga dapat berperan penuh terhadap perkembangan keluarganya untuk memberikan sistem pendidikan secara komprehensif, saling berkesinambungan, mulai dari anak tumbuh dari masa perkembangan, sampai masuk kedewasaan dan namun banyak orang tua yang sibuk dengan tugas pekerjaannya, sehingga tugas pokoknya dalam memperhatikan perkembangan anaknya waktu keluarga habis dengan aktivitasnya diluar rumah. Sehingga perhatiannya dalam keluarga tersita maka waktunya yang seharusnya terarah kepada anaknya terus terabaikan. Menurut Ningrum
(2020) bahwa faktor-faktor seperti dukungan dari orang tua dan dukungan dari masyarakat adalah faktor yang muncul dikarenakan adanya hubungan peserta didik sebagai bentuk pergaulannya dengan orang lain yang mempengaruhi pola perilakunya yang muncul baik di lingkungan keluarga, lingkungan sekolah, maupun lingkungan sekitar tempat tinggalnya. Jadi, salah satu faktor yang sangat penting dalam pembentukan sikap sosial sopan santun bagi anak adalah bentuk pola asuh atau pendidikan ketika dirumah yang diterapkan oleh orang tua tunggal terhadap anaknya.

\section{METODE PELAKSANAAN}

Penelitian ini akan dilaksanakan di tempat tinggal peneliti yaitu di Desa Karangsari Kecamatan Brati Kabupaten Grobogan Kode Pos 58153 dari bulan Agustus 2020 sampai dengan Januari 2021. Jenis penelitian yang digunakan adalah penelitian studi kasus. Metode yang digunakan dalam penelitian ini adalah studi kasus.

Pada penelitian ini akan difokuskan pada fenomena pola asuh yang dilakukan oleh keluarga tunggal dalam membentuk sikap sosial anaknya. Teknik pengumpulan data dengan menggunakan beberapa cara meliputi: observasi, wawancara, dan dokumentasi. Uji keabsahan data pada penelitian dengan menggunakan Teknik trianggulasi. Triangulasi yang dilakukan dengan triangulasi Teknik dan triangulasi sumber. Analisis data yang digunakan dengan reduksi data, display data dan verifikasi atau penyimpulan.

\section{HASIL DAN PEMBAHASAN}

\section{Sikap Sopan Santun Anak Di Lihat Dari Pola Asuh Orang Tua Tunggal}

Orang tua merupakan kunci utama dalam penerapan sopan santun anak sejak usia anak masih kecil. Sikap sopan santun merupakan salah satu aspek yang perlu ditanamkan oleh orang tua tunggal terhadap anaknya, sehingga anak tidak mengalami kesulitan berinteraksi saat memasuki usia remaja. Orang tua tunggal sangat memiliki peranan dalam lingkungan keluarga karena ia seorang diri dalam membesarkan dan mendidik anaknya, dan tidak dapat diberikan di lembaga pendidikan. Orang tua tunggal harus menciptakan kondisi lingkungan yang harmonis yang baik sehingga memungkinkan anak dapat mengembangkan sikap sopan santun pada dirinya. Dengan menggunakan 
bentuk pola asuh yang dianggap baik dan sesuai dengan karakter anak mampu membentuk sikap sosial santun anak dengan baik.

Bentuk pola asuh yang diterapkan oleh sebagian banyak informan orang tua tungal adalah bentuk pola asuh demokratis dan permisif. Bentuk pola asuh demokratis ini dilakukan dengan cara orang tua memberikan contoh yang baik terhadap anaknya dimana saat orang tua bertemu atau sedang bersama anaknya selalu berperilaku yang sesuai dengan nilai-nilai moral. Keteladanan yang dilakukan orang tua tidak harus berupa kalimat-kalimat yang diungkapkan sehari-hari tetapi juga bisa dengan contoh nyata tingkah laku orang tua tunggal. Dari contoh terebut anak dengan sendirinya akan meniru perbuatan seperti yang orang tua tunggal contohkan. Bentuk pola asuh permisif ini dilakukan adanya kebebasan tanpa batas kepada anak untuk berbuat dan berperilaku sesuai dengan keinginan anak. Orang tua tunggal tidak memberikan aturan yang mengikat kepada anak. Semua keputusan berada ditangan anak.

Berdasarkan hasil wawancara dan observasi yang telah dilakukan di desa Karangsari terdapat lima informan orang tua tunggal yang menggunakan bentuk pola asuh demokratis, dan dua informan orang tua tunggal yang menggunakan bentuk pola pengasuhan permisif. Untuk pola asuh otoriter dan campuran tidak ditemukan saat penelitian

\section{Pola Asuh Demokratis}

Orang tua tunggal SM, S, M, N, dan U menggunakan bentuk pola pengasuhan demokratis dalam menanamkan sikap santun pada anaknya. Orang tua tunggal menjadi salah satu teladan bagi anak-ankanya. Menanamkan sikap santun pada anak orang tua tunggal berusaha terbuka kepada anaknya yaitu dengan cara selalu menjaga komunikasi antara orang tua tunggal dengan anaknya. Komunikasi tersebut bisa berupa orang tua tunggal menanyakan kegiatan sehari-hari anak. Penanaman sikap santun menggunakan model demokratis membuat anak menjadi lebih aktif ketika berinteraksi dengan orang lain, bersosialisasi dengan orang lain, menolong teman, menghormati orang yang lebih tua, berani mengungkapkan pendapat, mendengarkan teman maupun orang yang lebih tua saat berbicara. Tetapi berbeda dengan ibu SM yang menggunakan model pola asuh demokratis tetapi sikap dari anaknya memiliki sikap kurang santun. Berdasarkan hasil observasi dan wawancara hal tersebut dikarenakan faktor dari lingkungan. Hal tersebut sesuai dengan pendapat Mansur Rosichin (2015) mengatakan bahwa lingkungan keluarga merupakan lingkungan yang pertama dan utama. Anak lahir dalam lingkungan keluarga dan pertama kali menerima pendidikan. Keluarga yang pertama internalisasi atau memberikan nilai-nilai kehidupan pada anak sebagai bekal hidup dalam mengarungi lautan kehidupan yang lebih luas kelak. Lingkungan keluarga dari ibu SM kurang mendukung dalam penanaman sikap santun anak. Ketika ibu SM sibuk bekerja mencari nafkah sedangkan anak dari ibu SM yang bernama NSS yang saat siang hingga sore hari banya menghabiskan waktu dengan nenek dan kakeknya yang memberikan dampak yang kurang baik bagi penanamna sikap sopan pada anak NSS walaupun bentuk pola asuh yang diterapkan oleh ibu SM adalah pola asuh demokratis. Nenek dan kakek dari NSS cenderung lebih suka berteriak-teriak saat menasehati NSS, saat berbicara dengan nada yang tinggi, dan tidak berbicara dengan lembut. Hal tersebut membuat NSS mudah menirukan apa yang nenek dan kakeknya lakukan disaat ibu SM bekerja.

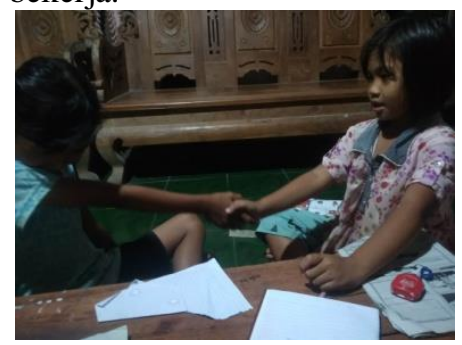

Gambar 1. Anak Meminta Maaf Saat

Melakukan Kesalahan

Model penanaman sikap sopan santun menggunakan bentuk pola pengasuhan demokratis selaras dengan hasil penelitian oleh Sri Lestari (Dalam Aziz 2017) bahwa metode yang digunakan oleh orang tua dalam melakukan sosialisasi terhadap anak, meliputi pemberian nasihat menggunakan bahsa yang mudah dipahami oleh anak. Pemberian nasehat dilakukan setelah anak melakukan pelanggaran aturan yang telah disepakati bersama. Orang tua tunggal memberikan teladan atau contoh secara nyata kepada anak, sehingga perilakuperilaku moral dapat dipahami secara konkret oleh anak, dan tidak menekan hukuman fisik dengan memukul, mencubit, teriakan keras, mengomeli anak yang telah melangar peraturan

\section{Pola Asuh Permisif}

Dari hasil wawancara dan observasi informan orang tua tungal $\mathrm{K}$ dan $\mathrm{D}$ 


\section{Reza Nur Faizah, Nur Fajrie, Ratri Rahayu \\ SIKAP SOPAN SANTUN ANAK DILIHAT DARI POLA ASUH ORANG TUA TUNGGAL \\ JURNAL PRASASTI ILMU. Volume 1 Nomor 1 hlm. 13-18}

menggunakan bentuk pola pengasuhan permisif. Dimana orang tua selalu menuruti keinginan anak. Apapun yang diinginkan anaknya selalu dituruti, yang terpenting anaknya tidak rewel, apalagi ibu $\mathrm{K}$ dan $\mathrm{D}$ bekerja dari pagi sampai sore, jadi mereka selalui menuruti keinginan dari anaknya sehingga anak tidak rewel. Tipe orang tua yang menggunakan bentuk pola pengasuhan permisif ditandai dengan adanya kebebasan yanpa batas kepada anak untuk berbuat dan berperilaku sesuai dengan keinginan anak. Orang tua tunggal tidak memberikan aturan ataupun arakan kepada anak. Semua keputusan yang akan diambil diserahkan kepada anak tanpa pertimbangan dari orang tua. Sehingga anak tidak mengetahui perbuatan yang dilakukan itu baik atau buruk bagi dirinya sendiri maupun bagi orang lain karena orang tua tunggal mereka tidak pernah menyalahkan ataupun membenarkan.

Model penanamna sikap santun ini juga dipengaruhi oleh ibu yang bekerja dari pagi sampai sore hari. Hal ini dapat dilihat dari informan ibu $\mathrm{K}$ dan $\mathrm{D}$ yang memiliki pekerjaan yang membutuhkan waktu dari pagi hingga sore hari, hal tersebut karena tuntutan ekonomi yang semakin tinggi, sehingga mereka harus bekerja lebih keras untuk memenuhi kebutuhan sehari-hari. Kondisi tersebut mengakibatkan penanaman sikap santun kepada anak menjadi terbengkalai dan anak menjadi mendapatkan kurangnya pengaasan dari orang tua tunggal mereka. Rasa lelah menjadikan ibu K dan D cenderung menuruti keinginan dari anaknya. Model pengasuhan permisif memberikan kebebasan penuh kepada anak untuk melakukan dan bertindak sesuai dengan keinginan anak. Terlihat dari orang tua tunggal $\mathrm{K}$ dan $\mathrm{D}$ kurang memberikan nasehat kepada anaknya, karena kesibukannya dalam bekerja, sehingga waktu yang dibutuhkan untuk menasehati anak sudah tidak ada. Orang tua tunggal tidak memberikan sanksi yang tegas, dan hanya memberikan intruksi yang kurang tegas yang belum tentu ditaati oleh anak.

Hal ini membuat anak menjadi mementingkan diri sendiri dan tidak menghiraukan hak-hak dari orang lain. Seperti yang terjadi pada anak yang bernama DW anak dari ibu D yang memiliki sikap yang kurang santun, ia terlihat mementing dirinya sendiri dan ketika berbicara dengan lawan bicaranya selalu menggunakan bahasa yang kurang lembut. Ketika diberi nasehat oleh ibunya maupun oleh orang lain sering membantah dan tidak menghiraukan nasehat itu. Hal tersebut dikarenakan ibu D tidak pernah memberikan aturan-atiran yang mengikat, serta terlalu membiarkan anaknya, sehingga anak berperilaku sesuai dengan keinginanya dan tidak mengetahui apakah yang dilakukan itu benar ataupun salah. Ibu D kurang memberikan sedikit waktu untuk mengontrol anaknya, karena sudah sibuk dengan pekerjaannya, dan ketika sudah sampai dirumah ibu D sudah lelah karena seharian bekerja mencari nafkah untuk keperluan ekonomi, karena tingkat perekonomian yang dialmi ibu $\mathrm{K}$ tergolong perekonomian yang menengah kebawah. Jadi tingkat perekonomian juga dapat mempengaruhi bentuk perhatian orang tua kepada anak. Seperti yang dijelaskan oleh Atika \& Rasyid (2018) mengungkapkan bahwa kemampuan sosial ekonomi orang tua merupakan sebuah latar belakang pencapaian poisi orang tua di masyarakat dapat mempengaruhi perkembangan anak. Anak yang lahir dari keluarga dengan status sosial ekonomi rendah cenderung beresiko terhadap perkembangannya. Perekonomian yang cukup berupa kepemilikan materi yang dihadapi anak didalam keluarganya akan berdampak bagi anak. Kondisi tersebut sangat baik bagi anak untuk ia mendapatkan kesempatan untuk memperkembangkan bermacam-macam kecakapan yang lebih luas. Jika seorang anak memiliki keluarga yang perekonomiannya rendah maka ketika ia memperkembangkan kecakapannya maka akan terhambat.

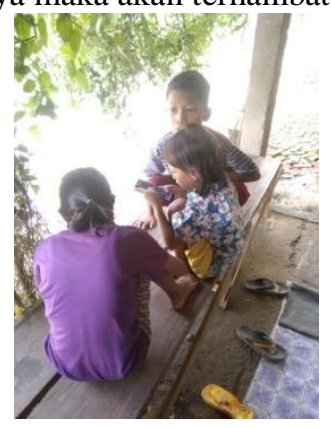

Gambar 2. Anak Berinteraksi dengan Temannya

Berbeda dengan anak dari informan $\mathrm{K}$, anak dari informan K yang bernama TBS lebih memiliki sikap yang santun. Meskipun ibu K menggunakan bentuk pola pengasuhan permisif, tetapi anak TBS tetap memiliki sikap yang santun. Hal itu disebabkan karena karakter asli dari TBS adalah termasuk anak yang pendiam dan penurut. Selain itu terdapat nenek dan kakek serta anggota keluarga lainnya yang peduli dengan TBS. Ketika ibu K bekerja diuar rumah dari pagi sampai siang hari TBS selalu diperhatikan oleh nenek dan kakek serta anggota keluarga lainnya, jadi sikap TBS 


\section{Reza Nur Faizah, Nur Fajrie, Ratri Rahayu \\ SIKAP SOPAN SANTUN ANAK DILIHAT DARI POLA ASUH ORANG TUA TUNGGAL \\ JURNAL PRASASTI ILMU. Volume 1 Nomor 1 hlm. 13-18}

masih terkontrol dengan baik walaupun ibu $\mathrm{K}$ menggunakan bentuk pola pengasuhan permisif. Tetapi ibu $\mathrm{K}$ tetap mengontrol TBS melalui handphone sebagai bentuk kasih sayang dari ibu K kepada TBS. Hal tersebut membuktikan bahwa lingkungan dapat mempengaruhi terbentuknya sikap anak. Lingkungan yang baik akan membuat anak tumbuh dengan baik, karena setiap hari ia mencontoh dari lingkungan yang baik tersebut. Jika lingkungan sekitar anak kurang mendukung, maka sikap anak juga akan terbentuk kurang baik, karena anak setiap harinya menirukan hal yang kurang baik di lingkungan sekitarnya. Sesuai dengan apa yang dikatakan oleh Hulukati (2015) bahwa lingkungan keluarga dapat berperan penuh terhadap perkembangan keluarganya untuk memberikan system pendidikan secara komprehensif, saling berkesinambungan, mulai dari anak mulai tumbuh dari masa perkembangan sampau masuk kedewasaan.

\section{KESIMPULAN}

Orang tua merupakan kunci utama dalam penanaman sikap sopan santun pada anak sejak usia dini. Apalagi keluarga yang hanya memiliki satu orang tua saja. Orang tua tunggal memiliki peranan dalam lingkungan keluarga, dan tidak dapat diberikan di lembaga pendidikan. Pola asuh yang digunakan oleh ke tujuh subyek dalam penelitian ini dapat dibedakan menjadi dua bentuk pola asuh yakni pola asuh permisif dan pola asuh demokratis. Kebanyakan anak yang diasuh menggunakan pola pengasuhan demokratis maka akan membentuk sikap santun yang baik. Adapun faktor-faktor yang mempengaruhi terbentuknya sikap santun pada anak adalah karena faktor lingkungan dan faktor ekonomi.

\section{DAFTAR PUSTAKA}

Atika, A. N., \& Rasyid, H. (2018). Dampak Status Sosial Ekonomi Orang Tua Terhadap Keterampilan Sosial Anak. Jurnal Pendidikan. 3833, 111-120.

Aziz, O. F., Sekolah, P. L., \& Yogyakarta, U. N. (2017). Parent"s Role To Implant The Childhood Discipline In Family Environment (Case Study In Dusun Kukap Desa Poncosari Kecamatan Srandakan) Oleh: Obi Faizal Aziz, Pendidikan Luar Sekolah, Universitas Negeri Yogyakarta. 1(September), 158-171.
Isma Nur (2017). Peranan Orang Tua Tunggal (Single Parent) Dalam Pendidikan Moral Anak (Studi Kasusu delapan Orang Ayah Di Desa Songing Kecamatan Sinjai Selatan Kabupaten Sinjai). Jurnal Sosialisasi Pendidikan Sosiologi. 1-5

Ningrum, R. W., Ismaya, E. A., Fajrie, N., \& Artikel, S. (2020). Faktor - Faktor Pembentuk Karakter Disiplin dan Tanggung Jawab Dalam Ekstrakurikuler Pramuka. 2020, 3(1), 105-1117.

Pinem, M. (2016). Pengaruh Pendidikan dan Status Sosial Ekonomi Kepala Keluarga bagi Kesehatan Lingkungan Masyarakat. Jurnal Pendidikan. 4(1), 97-106.

Puspa Djuwita (2017). Pembinaan Etika Sopan Santun Peserta Didik Kelas V Melalui Pembelajaran Pendidikan Kewarganegaraan. Jurnal Pendidikan. 10(1), 27-36

Rahayu, R., Guru, P., \& Dasar, S. (2014). Faktor-faktor yang mempengaruhi kepercayaan diri siswa kelas viii dalam menyelesaikan masalah matematika pada model pmri. 1-11

Samsiyah, S., Hanif, M., \& Parji, P. (2020). Peningkatan Sopan-Santun dan Disiplin melalui Tembang Dolanan pada Siswa TKIT Al Furqon Maospati Magetan Improvement of Polite and Discipline through Dolanan Song for TKIT Al Furqon Maospati Magetan Students. Jurnal Pendidikan. 5(1), 4051.

Wiranti, D. A. \& Much Arsyad Fardani (2019). Peran orang tua dalam pengembangan bahasa jawa krama anak usia dini. Prosiding Seminar Nasional. 0291, 117-122

Zamroni, A. (2017). Strategi Pendidikan Akhlak Pada Anak. Jurnal Pendidikan. 12(4), 241-264. 